\title{
O Jornal Vascular Brasileiro é o espelho da Sociedade Brasileira de Angiologia e de Cirurgia Vascular
}

\author{
Jornal Vascular Brasileiro reflects the Brazilian Society of Angiology \\ and Vascular Surgery
}

Winston Bonetti Yoshida*

Findo o Congresso Brasileiro de Angiologia e Cirurgia Vascular, procuremos refletir um pouco sobre a relação entre este e o Jornal Vascular Brasileiro (J Vasc Bras).

Tradicionalmente (e neste recente congresso não seria diferente), os colegas de nossa sociedade apresentaram grande número de temas livres. Ocorre até uma saudável competição entre os serviços no sentido de ver qual leva o maior número de resumos para as várias sessões dos congressos. No entanto, é preciso salientar que trabalho não publicado NÃO EXISTE.

Os temas livres não são compilados por nenhum recurso de bibliometria, como fator de impacto ou citação do fator H. Além disso, eles não contam pontos para revalidação de título de especialista, costumam ser vistos por poucos e não são lidos por absolutamente ninguém. Sua publicação em anais de congressos é mera formalidade e registro e não confere nenhuma vantagem para os autores em termos curriculares e de concursos.

Por outro lado, os bons temas livres demandam um grande investimento em termos de tempo e dedicação, e isso pode e deve ser aproveitado: o levantamento bibliográfico já foi feito, a estrutura geral foi montada, os resultados foram compilados e analisados estatisticamente, e as conclusões, obtidas. Fica faltando realmente muito pouco para o tema livre se transformar em um artigo a ser submetido para nossa revista ${ }^{1}$.

Evidentemente, escrever o artigo completo não garante que ele vá ser publicado. Este precisa passar por avaliação por pares (peer-review) e pelo editor para ser apro- vado. No entanto, uma vez aprovado, confere valorização aos autores e ao serviço que representam.

O J Vasc Bras está atravessando um período de certa turbulência em função das novas normas de qualificação de revistas nacionais pela CAPES. O novo critério, apoiado exclusivamente no fator de impacto, calculado pela empresa privada Thomson-Reuters (ISI), causa grande prejuízo ao nosso jornal e às revistas nacionais ${ }^{2}$. Ao mesmo tempo em que o CNPq apoia nossa revista com ajuda financeira, a CAPES desqualifica qualquer publicação na mesma. É preciso considerar que o processo de amadurecimento de uma revista é bastante demorado. Só para exemplificar, um dos periódicos mais importantes em medicina, o New England Journal of Medicine, foi fundado em 1812!

Fizemos gestões junto à Associação Médica Brasileira (AMB) e Associação Brasileira de Editores Científicos (ABEC) no sentido de provocar uma discussão ampla destes novos critérios com a CAPES e esperamos que este movimento possa redundar em reversão deste descalabro. O tema está repercutindo negativamente em vários setores da ciência brasileira ${ }^{3}$.

Enquanto não acontece essa reversão, o nosso jornal precisa urgentemente do apoio e suporte dos colegas da Sociedade Brasileira de Angiologia e de Cirurgia Vascular (SBACV) através do envio de um número suplementar de artigos originais.

É preciso salientar também que o J Vasc Bras é o espelho da SBACV. Ele concentra o que há de melhor em termos da produção científica de nossa sociedade, e nele se

\footnotetext{
* Editor-Chefe, J Vasc Bras.

Não foram declarados conflitos de interesse associados à publicação deste editorial. 
baseiam organizações, instituições, índices bibliométricos e população em geral para avaliar e fazer juízo de valores sobre ela. Se o J Vasc Bras sucumbir por desinteresse dos colegas e a consequente falta de produção de artigos ${ }^{4}$, a SBACV sucumbirá também. A falta de credibilidade assim gerada será repassada para todos os profissionais da especialidade.

Neste momento de dificuldades, que esperamos seja transitório, conclamamos todos a fazer um esforço concentrado no sentido de apoiar o J Vasc Bras com o envio de grande número de artigos.

\section{Referências}

1. Yoshida WB. Temas livres versus publicação. J Vasc Bras. 2005;4:319-20.

2. Rocha-e-Silva M. O novo Qualis, ou a tragédia anunciada. Clinics. 2009;64:1-4.

3. Escobar H. [notícia na internet] Ranking coloca revistas científicas brasileiras em "risco de extinção". O Estadão. Acessado: 29/07/2009. http://www.estadao.com.br/estadaodehoje/20090706/not_i mp398294,0.php

4. Moreira RC. Por que os cirurgiões vasculares brasileiros publicam tão pouco? J Vasc Bras. 2008;7:291-2. 